\title{
Uplatnění paravoltiže v rámci léčebné hipoterapie
}

\section{Use of Paravaulting within Therapeutic Riding}

\author{
Jana Sklenaříková \\ Fakulta tělesné kultury, Univerzita Palackého, Olomouc, \\ Česká republika
}

\section{Abstrakt:}

Paravoltiž neboli akrobacie na koni je jednou z mnoha rehabilitačních metod založených na léčebném ježdění a zároveñ je to jezdecká sportovni disciplina pro osoby se zdravotním postižením. Paravoltiž je vákladech shodná s voltiži, je ale přizpůsobená jedinci s postižením. Cílem práce bylo navrhnout modelovou motorickou prípravu pro trénink paravoltiže, která do dnešního dne nebyla sepsána. Do tréninkové jednotky paravoltiže byly zařazeny prvky základni rytmické a sportovní gymnastiky. Tréninky byly navrženy s cilem zlepšit orientaci, rovnováhu a celkovou obratnost. Při aplikaci gymnastických cvičení do pohybového programu bylo nutné vycházet $z$ informace, že zaměrení muselo odpovídat psychickým možnostem jednotlivých probandů, jejich zdravotnímu stavu a specifikace postižení.

\section{Abstract:}

Paravaulting or acrobatics on the horseback is one of many rehabilitation methods based on therapeutic riding and is a sports event for people with disabilities. Paravaulting is basically identical to the vaulting but is tailored to individuals with disabilities. The aim was to design a regular motor preparation for training paravaulting which has not been written till present. Gymnastic exercises were included in the training unit of paravaulting. Workouts are designed to improve orientation, balance and overall agility. During applying gymnastic exerci- 
ses in motion program had to be based on information that the focus had to match the mental abilities of individual probands, their condition and specifics of disability.

Klíčová slova: hipoterapie, paravoltiž, kưn̆, trénink, gymnastika.

Key words: hippotherapy, paravaulting, horse, training, gymnastic.

Tento př́spěvek vznikl v rámci projektu: „Podpora vytváření excelentních týmů a intersektorální mobility na Univerzitě Palackého v Olomouci II. “, reg. č. CZ.1.07/2.3.00/30.0041.

\section{ÚVOD}

Světová zdravotnická organizace (WHO) definuje zdraví jako stav kompletní fyzické, mentální a sociální pohody. Jsou-li však některé schopnosti jedince sníženy, omezeny nebo chybí-li některé úplně, mluvíme pak o handicapu (vadě, poruše, postižení, defektu nebo znevýhodnění). Jedinec $\mathrm{s}$ handicapem se může se svým postižením různě vyrovnat. Pokud je se svou vadou smířený a postižení nemá negativní vliv na jeho psychiku, ani na společenské vztahy a nedeformuje jeho osobnost, je postižení jeho osobní záležitostí. Pokud se však vada odráží v psychice jedince a ovlivňuje jeho společenské vztahy, vztahy k výchově, ke vzdělávání nebo k práci, mluvíme o člověku postiženým defektivitou. Příčinnou bývá často nevhodná reakce prostředí na handicap (Ježková, 2004).

$\mathrm{S}$ prítomností handicapovaných osob se lidstvo setkávalo v každé době a v každém společenství a jednotlivci i celá společnost se vždy museli nějakým způsobem vyrovnávat se svými takto odlišnými členy. Tento vztah se ale v průběhu dějin proměňoval, a to v závislosti na vývoji společnosti, s vývojem myšlenkových proudů, společenských paradigmat nebo filozofických názorů. I navzdory velmi negativně vymezovaného vztahu společnosti ke znevýhodněným členům ve starověku, kdy docházelo ke zbavování se nemocných a jakkoli postižených členů 
společnosti, kteří byli chápáni jako slabí a pro společnost nepotřební, existují stopy pomoci a péče o jedince $\mathrm{s}$ postižením už i v této době (Slowík, 2007); (Vágnerová, Hadj-Moussová \& Štech, 2001).

Existence lidí s postižením je přirozeným, běžným a tedy i normálním jevem, který se vždy vyskytoval, vyskytuje a vyskytovat bude ve všech obdobích a společnostech. I prres veškerou snahu lékařských a technických věd je zřejmé, že patrně nikdy nevymizí nemoci a úrazy působící trvalé zdravotní postižení (Krhutová, 2010).

\section{HLAVNÍ ČÁST \\ Paravoltiž}

Paravoltiž je v základech shodná s voltiží, což je jezdecká disciplína, charakterizována jako gymnastika či akrobacie na koni, je ale přizpůsobená jedinci s postižením - paravoltižérovi, který vykonává na neosedlaném koni gymnastické cviky. Cvičí samostatně nebo ve dvojici. Paravoltiž klade vysoké nároky na fyzickou kondici, je určena pro jedince s určitým typem postižení (Zelinka, 2007).

Je jednou z mála možností pro zdravotně handicapovanou populaci stát se součástí sportovního dění. Je vhodná zejména pro ty postižené, kteří mají chut' poprat se se svým handicapem a mají doporučení k tomuto sportu od lékaře. Jedná se o pohybově náročnou disciplínu, která klade vysoké požadavky na koordinaci pohybu a na kloubní pohyblivost. Paravoltižér musí zvládat cvičení na poměrně malé, neustále se pohybující ploše, kterou představuje hřbet koně.

\section{Cíle paravoltiže}

Rovněž jako ostatní formy hiporehabilitace má i paravoltiž své specifické cíle. Jedná se především o rozvoj a zdokonalování pohybových schopností zdravotně postižených jedinců v rámci jejich možnosti zlepšování psychické kondice a schopnosti spolupráce s ostatními členy týmu. Jedním z cílů je také podporování samostatnosti, tvořivosti a zvyšování sebevědomí jedinců. Cvičení by mělo vést k pocitům uspokojení 
a radosti $\mathrm{z}$ dosažených výsledků a $\mathrm{k}$ motivaci $\mathrm{k}$ dalším výkonům. Paravoltižér by se měl naučit prostorově vnímat své tělo, polohy částí svého těla, ovládat napětí ve svalech a umět držet vzpřímené postavení páteře (Faksová, 2004).

Cvičenci jsou klasifikováni do kategorií, které provádí lékař nebo fyzioterapeut s kurzem klasifikátora:

- LH - lehký zdravotní handicap (skolióza, vadné držení těla, lehká smyslová a srdeční vada, epilepsie, astma, diabetes melitus, neuróza, lehká mozková dysfunkce, specifické poruchy učení a chování).

- MH - mentální handicap (mentální retardace).

- TH - těžký zdravotní handicap (periferní obrny, deformace a amputace končetin, těžší smyslové vady, kombinované vady).

\section{Tréninkový model paravoltiže}

Cvičenec paravoltiže by se měl naučit časově i prostorově vnímat své tělo. Měl by se také naučit vnímat polohu částí těla, ovládat napětí ve svalech a umět držet vzpř́mený sed.

Tréninková jednotka by měla být sestavena tak, aby odpovídala obecným požadavkům na stavbu tréninku a přizpůsobena specifičnosti práce u koní a práci s postiženými cvičenci. Pro paravoltižéry je důležité, aby se schéma tréninkového dne měnilo co nejméně. Cvičenci si již po několika trénincích pamatovali, co bude následovat a znali své povinnosti, což značně přispívalo k rychlejšímu a hladšímu průběhu tréninku.

Základní pohybovou schopností, která se se při tréninku využívá, je síla. Jak dynamická, pomocí které cvičenci provádějí švihové cviky, tak také síla statická. Ta je zapotřebí při cvičení, respektive při výdrži jednotlivých cviků a to na čtyři doby představující čtyřri kroky koně. Tyto čtyři doby představují pravidelný rytmus koně, který pomáhá při cvičení. Paravoltiž je tedy rytmické cvičení, kdy rytmus koně vede k navození koncentrace a stavu uvolnění cvičence. 


\section{Metodika práce}

Do tréninkové jednotky paravoltiže byly zařazeny prvky základní rytmické a sportovní gymnastiky. Tréninky byly navrženy s cílem zlepšit orientaci, rovnováhu a celkovou obratnost (viz. př́loha 1). Při aplikaci gymnastických cvičení do pohybového programu bylo nutné vycházet z informace, že zaměření muselo odpovídat psychickým možnostem jednotlivých probandů, jejich zdravotnímu stavu a specifikace postižení. Pohybový program byl sestaven na základě odborné literatury a empirických zkušeností. Výběr cviků jsme konzultovali s předsedkyní české hiporahabilitační společnosti, která se specializuje na paravoltiž a dále s lékařkou, která má dlouholeté zkušenosti s hipoterapií. Gymnastické cvičení bylo zaměřeno zejména na protahování zkrácených posturálních svalů, na správné držení těla a posilování jednotlivých svalů a svalových skupin.

Koordinaci pohybu a udržení svalové rovnováhy nelze dosáhnout pokaždé, a někdy je to zcela nemožné, nicméně cvičení je velmi důležité, protože napomáhá $\mathrm{k}$ optimalizaci jednotlivých funkcí vnitřních orgánů a psychické i sociální pohodě. Pro jedince s postižením je harmonizace pohybového programu zvlášt' důležitá.

Hlavní důraz je kladen na co možná nejpřesnější provedení jednotlivých cvičení a možnost přizpůsobit pohybový program individuálním zvláštnostem cvičících (Bursová, 2005).

Účelem tréninkových jednotek bylo prrispívat svými specifickými prostředky $\mathrm{k}$ rozvoji (ke kultivaci) osobnosti každého cvičence $\mathrm{v}$ rámci jeho omezených možností, zejména zajištěním optimálního tělesného a pohybového rozvoje.

Tréninkový model paravoltiže byl uplatňován v jezdeckém oddíle Fany Hostěnice, kde se oddíl kromě hipoterapie specializuje na sport osob se zdravotním handicapem. Oddíl má cca 20 členů různého věku, pohlaví i rozsahu postižení. Tato studie nebyla zaměřena na vybraný soubor, nýbrž na celou nehomogenní skupinu. Modelová motorická př́íprava pro trénink paravoltiže“ může být chápána jako přípravný program i pro 
úplné začátečníky, jelikož se schéma tréninků se víceméně v průběhu roku neměnilo. Metody ověření účinnosti programu jsme zvolili pozorováním.

Úvodní část pohybového programu byla zaměřena na zahřátí organismu, kloubně-mobilizační cvičení a následného protažení všech svalových partií a dále na cviky zejména na rozvoj dostatečné pohyblivosti všech kloubních struktur.

V další části jsme se zaměřili na speciální průpravné cviky pro paravoltiž. Cviky byly sestaveny do programu na rozvoj pohybových dovedností, které jsou potřeba u správného provedení závodních sestav, jež jsou popsané v pravidlech paravoltiže (viz. Př́loha 1). Některá cvičení byla prováděna $\mathrm{v}$ rámci kooperace ve dvojicích. Jednodušší tvary ve dvojici cvičenec + cvičenec, složiť̌jší tvary ve dvojici cvičenec + trenér. Výhodou cvičení ve dvou byl nácvik sociálního chování, větší kontrola provedení cviků a okamžitá náprava chyb. Cvičení byla mnohostranná a vyžadovali menší náročnost na pomůcky. Takto koncipovaná cvičení mohou mít i své nevýhody. Je to především vyšší časová náročnost, strach z dotyku a sociálního odmítnutí, nebezpečí chybného provedení cvičení, při nerovném počtu cvičenců musí učitel více spolupracovat (Jordan \& Graeber, 2004).

Dále bylo při trénincích nutné dodržet základní fyziologické a didaktické zásady popsané Vilímovou (2009) a to zejména: zásadu přiměřenosti, názornosti, aktivity a uvědomělosti, postupnosti a soustavnosti, trvalosti a emocionálnosti.

Podstatnou součástí programu byla zpětná vazba (reflexe, rewiew, ohlédnutí se). Skupina se učila dávat zpětnou vazbu a respektovat názory a pohledy ostatních.

Celá cvičební jednotka trvala přibližně 120 minut, včetně nachystání koně na jízdu a závěrečném odstrojení koně po cvičení. 


\section{Časový návrh skladby tréninkové jednotky:}

Úvodní část:

- rušná část + průpravná část

- průpravné cviky na zemi

Hlavní část:

- trenažér

- trénink na koni

- závěrečná část, zhodnocení cca 5 minut cca 30 minut cca 15 minut

cca 20 minut

cca 40 minut

cca 10 minut

\section{ÚVODNÍ ČÁST TRÉNINKOVÉ JEDNOTKY}

- zápis prezence

- vysvětlení náplně tréninku

- zjištění aktuálního zdravotního stavu cvičenců

\section{Rušná část, průpravná část}

Složení rozcvičení bylo stanoveno ihned na začátku mého působení u paravoltiže a dále se téměř neměnilo, aby si jej cvičenci dobře zapamatovali. Cviky do rozcvičení pro paravoltižéry bylo třeba vybírat mimořádně pečlivě. Bylo nutné vyhledat cviky, které jsou jednoduché na zacvičení, tak aby je prováděli technicky správně a účelně. Je důležitý metodický postup při aplikaci pohybového programu. Odborný vyškolený asistent (trenér) sám zvolený cvik předcvičuje a doprovází jej slovní instrukcí. Klient dospělého napodobuje. U obtižň̌jších cviků je třeba zvolit analyticko-syntetickou metodu a postupovat po jednotlivých fázích. Neprovede-li paravoltižér cvik správně ani po opakované slovní instrukci a nedaří-li se nápodoba, pomůže mu dospělý při provedení cviku, popř. jej celým cvikem vede, takže klient cvičí pasivně. $V$ dalším opakování již vede k samostatnému aktivnímu provedení podle nápodoby.

\section{Rušná část}

Předchází dynamickému rozcvičení, slouží k zahřátí organismu. Cílem rušné části je zrychlení tepové frekvence organismu, uvolnění psy- 
chického napětí a vytvoření př́ijemné atmosféry pro další části hodiny. Prostředkem rušné části by měla být přirozená tělesná cvičení se středním rovnoměrným fyzickým zatížením. Probíhá především na jízdárně, proto se $\mathrm{k}$ určení délky a vzdálenostem používají jízdárenská označení. Např. dlouhá stěna - cca $60 \mathrm{~m}$, krátká stěna - cca $20 \mathrm{~m}$, celá jízdárna cca $160 \mathrm{~m}$.

\section{Průpravné cviky na zemi}

V pravidelném tréninku se vybírají průpravné cviky podle toho, na který prvek z povinné nebo volné sestavy je trénink zaměřen. Tyto cviky jsou důležité pro zvládnutí správné techniky provedení. Rovněž slouží ke zlepšení koordinačních schopností a k posílení svalů zapojovaných $\mathrm{v}$ daném cviku a $\mathrm{k}$ naučení se jejich správného zapojení.

Zde využíváme terminologické značkové názvy, které odpovídají užívanému názvosloví v paravoltiži.

\section{HLAVNÍ ČÁST TRÉNINKOVÉ JEDNOTKY}

\section{Př́́prava koně:}

- vyčištění koně (hřebelcování, kartáčování, péče o kopyta);

- př́prava postrojů;

- pomoc při uzdění a chystání koně na trénink pod vedením trenéra.

\section{Průpravné cviky na trenažéru:}

Na začátek jsou řazeny dynamické i statické cviky na rozcvičení a sžití se s trenažérem. Všechny cviky, které budou cvičenci předvádět na koni, by měli provést na trenažéru:

\section{Práce na koni}

Při tréninku vede lonžér koně stř́davě na levou i pravou stranu, aby nedošlo $\mathrm{k}$ jednostrannému přetížení koně. Cvičenci se střídají jeden po druhém. 
Trénink na koni je obvykle zaměřen na určitý cvik nebo kombinaci cviků z povinné nebo volné sestavy.

\section{ZÁVĚREČNÁ ČÁST}

V závěrečné části dbáme na zklidnění organismu po stránce fyziologické i psychické. Součástí této části bývá zhodnocení hodiny nejen trenérem, ale i cvičenci, jež může být velkým př́nosem pro trenéry v plánování následujících tréninků.

- Pochválení koně po tréninku.

- Zhodnocení tréninku.

\section{ZÁVĚR}

Během svého aktivního působení v jezdeckých oddílech trénuji skupinu zdravých dětí i handicapovaných dětí a mohu tak porovnat rozdíly $\mathrm{v}$ prístupu zdravých a postižených cvičenců $\mathrm{k}$ tréninku. $\mathrm{Z}$ důvodů integrace a společných tréninků je schéma tréninkové jednotky většinou stejné. Z tohoto faktu musím vyhodnotit, že mnohem kvalitnější přístup k tréninku mají paravoltižní cvičenci. Na tréninky se velice těší, mají chut' se naučit něco nového a dokázat, že mohou sportovat jako všichni ostatní. Po určité době se cvičenci postupně zbavili úzkosti a následně docházelo u některých $\mathrm{k}$ odstranění agresivity, antipatií a ke zlepšení celkové kondice. Nicméně trénovat postižené je obtížnější a to především proto, že se nejedná o skupinu se stejným handicapem a je nutné ke každému přistupovat extrémně individuálně. Trenér musí být často psycholog a lékař, ale především musí mít obrovskou dávku trpělivosti.

Ze zkušenosti mohu uvést, že soutěže a vystoupení mají velice pozitivní vliv na handicapované jedince. Kromě upomínkových předmětů a kokard, které jsou silným motivačním prvkem, je také velkou odměnou pro cvičence a i jejich trenéry potlesk publika.

Z práce vyplývají následující závěry pro praxi, které můžeme doporučit pro trenéry, hipology a zájemce o paravoltiž:

- věnovat se každému cvičenci individuálně, podle postižení; 
- tréninky by měly být dobře rozvrženy s ohledem na individuální prístup;

- při tvorbě volných sestav je důležité brát ohled na možnosti cvičence, nicméně cvičence je třeba podporovat v učení se novým obtížnějším cvikům.

\section{LITERATURA}

Bursová, M. (2005). Kompenzační cvičení: uvolňovací - posilovací protahovací. Praha: Grada.

Faksová, M. (2004). Paravoltiž. Olomouc: Katedra Aplikované tělesné výchovy.

Ježková, A. (2004). Paravoltiž. Praha: Česká hiporehabilitační společnost.

Ježková, A., Jablonská, J., \& Blažek, D. (2006). Paravoltižní pravidla ( $3^{\text {rd }}$ ed.). Praha: Česká hiporehabilitační společnost.

Jordan, A., \& Graeber, I. (2004). Fitness zu zweit PartnergymnastikDehnen und Kräftigen. Aachen: Meyer \& Meyer Fachverlag.

Krhutová, L. (2010). Teorie a modely zdravotního postižení. Sociální práce.

Slowík, J. (2007). Speciální pedagogika. Praha: Grada Publishing.

Vágnerová, M., Hadj-Moussová, Z., \& Štech, S. (2004). Psychologie handicapu. Praha: Karolinum.

Vilímová, V. (2009). Didaktika tělesné výchovy. Brno: Masarykova univerzita.

Zelinka, J. (2007). Absolventská práce. Paravoltiž a Hipoterapie. Praha: Palestra.

\section{KONTAKT:}

Mgr. Jana Sklenaříková, Ph.D., jana.sklenarikova@upol.cz 


\section{Př́́LOHA 1}

\section{Rušná část}

Probíhá především v kryté hale nebo na venkovní jízdárně, proto se k určení délky a vzdálenostem používají jízdárenská označení: dlouhá stěna - cca $60 \mathrm{~m}$, krátká stěna - cca $20 \mathrm{~m}$, celá jízdárna - cca 160 m.

- Klus, $1 \times$ jízdárna;

- cval stranou, $1 \times$ jízdárna;

- lifting, 1× dlouhá stěna + krátká stěna;

- skipping, $2 \times$ dlouhá stěna;

- rychlý klus, $2 \times$ krátká stěna;

- zrychlená chůze, $1 \times$ celá jízdárna.

\section{Průpravná část}

1. Stoj rozkročný, připažit - půlkruhy hlavou zprava do leva a zpět;

2. stoj rozkročný, kroužení ramen;

3. stoj spojný, vzpažit - hmitem podřepmo bočné oblouky vpřed do zapažení a zpět;

4. stoj rozkročný, upažit, kroužení zápěstím/předloktím/paží v čelné rovině $\mathrm{P} / \mathrm{L}$ (př́loha 1 , obr. 42 );

5. stoj rozkročný, kroužení trupem $\mathrm{P} / \mathrm{L}$;

6. stoj rozkročný, vzpažit, úklony $\mathrm{P} / \mathrm{L}$;

7. stoj, unožit $\mathrm{P}$, přenosem podřep unožit $\mathrm{L}$;

8. stoj spojný, poskokem vzpor dřepmo, odrazem vzpor ležmo;

9. vzpor klečmo únožný $\mathrm{P} / \mathrm{L}$, vzpažit $\mathrm{P} / \mathrm{L}$ - výdrž;

10. vzpor klečmo - vzpor klečmo ohnutě a prohnutě;

11. sed skrčmo roznožný, ruce v týl, otočit trup vpravo a vlevo;

12. turecký sed, ruce v týl, hluboký ohnutý předklon;

13. sed roznožný, vzpažit, hluboký ohnutý předklon $\mathrm{k} P / \mathrm{L}$;

14. překážkový sed $\mathrm{P} / \mathrm{L}$, vzpažit, hluboký ohnutý předklon, prsty na podložku; 
15. leh, skrčit přednožmo $\mathrm{P} / \mathrm{L}$ povýšs, dlaně na bérec, koleno $\mathrm{P} / \mathrm{L}$ přitáhnout k hrudníku;

16. leh, přednožit švihem $\mathrm{P} / \mathrm{L}$ a zpět;

17. čelný rozštěp;

18. bočný rozštěp.

\section{Cvičení ve dvojicích}

19. Dvojice stoj spojný zády k sobě, zapažit, uchopit se za ruce bočné kruhy vzad a vpřed;

20. dvojice stoj rozkročný proti sobě, předpažit, opřít dlaně - klik a zpět;

21. dvojice stoj rozkročný zády k sobě, vzpažit zevnitř vzad, uchopit se za ruce - podřep únožný $\mathrm{P} / \mathrm{L}$, úklon vpravo vlevo;

22. dvojice stoj spojný, rovný předklon, vzpažit ruce spojit - váha předklonmo;

23. dvojice klek zády k sobě, vzpažit zevnitř, uchopit se za ruce zvolna záklon, druhý zvolna předklon;

24. dvojice dřep zády k sobě, skrčit zapažmo a zaklesnout se za lokty - vztyk do stoje spojného;

25. dvojice sed skrčmo čelem $\mathrm{k}$ sobě, predpažit, uchopit se za ruce přednožit $\mathrm{P} / \mathrm{L}$;

26. dvojice sed roznožný čelem $\mathrm{k}$ sobě, předpažit $\mathrm{P}$, uchopit se za ruce, vzpažit L - úklon;

27. dvojice sed roznožný čelem k sobě, předpažit, uchopit se za ruce, hluboký ohnutý předklon a leh;

28. dvojice leh hlavami k sobě, vzpažit zevnitř, uchopit se za ruce přednožit povýš.

\section{Akrobacie}

29. kolíbka - leh, skrčit přednožmo, dlaně na bérec, švihem kolíbka vpřed do sedu, do dřepu, do stoje;

30. kolíbka ze stoje spojného - dřep, kolíbka, dřep, stoj spojný; 
31. kotoul vpřed na šikmé ploše;

32. kotoul vpřed z dřepu do dřepu na rovné ploše;

33. kotoul vpřed s míčem mezi stehny a hrudníkem;

34. kolíbka vzad, nácvik dohmatu - ze sedu skrčmo, ze vzporu;

35. kotoul vzad ze zvýšené plochy;

36. různé variace akrobatických sestav složených z osvojených prvkủ (leh vznesmo);

37. stoj na lopatkách, kotoul vpřed atd.

38. stoj na rukou:

39. vzpor ležmo, výdrž;

40. vzpor dřepmo - vzpor ležmo - vzpor dřepmo;

41. vzpor ležmo, nohy na zvýšené podložce, výdrž;

42. stoj na rukou ze vzporu ležmo zanožením švihové nohy;

43. stoj na rukou ze stoje.

\section{Hlavní část - průpravné cviky na zemi}

Využíváme terminologické značkové názvy, které odpovídají užívanému názvosloví v paravoltiži.

\section{Náskok:}

44. „Švihová holubička“ (obr. 14) - cvičenec předvede tři kroky ve vzpažení. Při čtvrtém kroku provede hluboký předklon a švihne $\mathrm{P} / \mathrm{L}$ do zanožení povýš. Trup a horní končetiny se pohybují směrem dolů a P/L nahoru, osa otáčení je v kyčelním kloubu. Konečnou fází cviku je vzpor stojmo se zanožením.

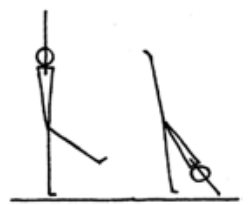

Obr. 14: „Švihová holubička“ 
45. „Náskokový“ stoj na rukou (obr. 15) - pro zdatnější cvičence. $\mathrm{V}$ asistovaném stoji na rukou cvičenec spustí levou dolní končetinu co nejníže.

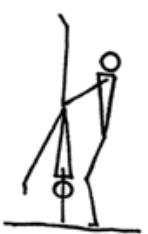

Obr. 15: „Náskokový“ stoj na rukou

\section{Základní sed s upažením}

46. „Prkýnko“ - cvičenec si opře celé předloktí a ruku na rovnou desku, aby měl dokonale propnuté dlaně a prsty, ruce $\mathrm{v}$ jedné prímce s předloktím. Poté paže zvedne a musí udržet stejnou pozici rukou.

47. „Zrcadlo“ - upažení před zrcadlem, konečky prstů ve výši očí, cvičenec vidí, $v$ jaké pozici mají paže být.

48. „Letadlo“ (obr. 16) - stoj rozkročný, upažit povýš, konečky prstů ve výši očí, úklony vlevo vpravo.

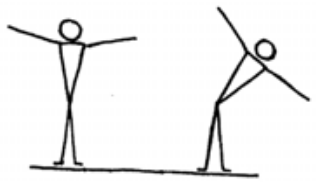

Obr. 16: „Letadlo“ (Zdroj: vlastní archiv)

\section{Holubička}

49. „Trakař“ (obr. 17, příloha 1: obr. 45) - ve dvojici, jeden z cvičenců ve výchozí pozici pro holubičku, druhý ho uchopí za kotníky a zvedne do vzporu ležmo. 

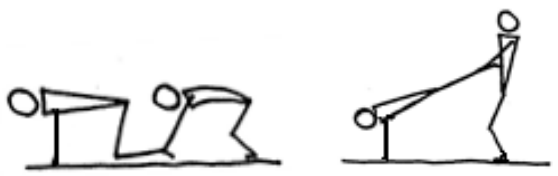

Obr. 17: „Trakař“ (Zdroj: vlastní archiv)

50. „Superman“ - leh na břiše, vzpažit, současně vzpažit vzad a zanožit, výdrž.

51. „Váha v lehu“ (obr. 18) - leh na břiše vzpažit. Zanožit P, vzpažit vzad L a opačně, výdrž.

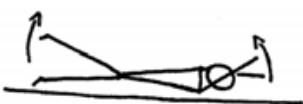

Obr. 18: „Váha v lehu“ (Zdroj: vlastní archiv)

52. „Váha“ (obr. 19, př́loha 1: obr. 46) - vzpor klečmo, mírný záklon hlavy, zanožit $P$, vzpažit vzad L a opačně.

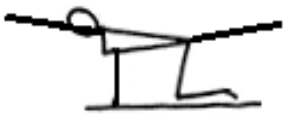

Obr. 19: „Váha“ (Zdroj: vlastní archiv)

53. „Holubička“ a narušení stability - „Holubička“ dle pravidel. Mírným tlakem do zanožené nohy směrem dolů a do stran se snažíme vyvést cvičence z rovnováhy, ten "absorbuje pohyby koně" a snaží se udržet rovnováhu.

\section{Mlýn}

54. „Kan-kán“ - stoj u opory, přednožit povýš P/L, unožit povýš P/L. Žádná jiná část těla, kromě nohou, nevykonává pohyb. Provést na 4 počítací doby, tak jak je cvik Mlýn popsaný v pravidlech. 
55. „Vláček“ (obr. 20, př́íloha 1: obr. 43) - sed roznožný za sebe. Obloukem $\mathrm{P} / \mathrm{L}$ přešvih nohy přes cvičence před sebou.

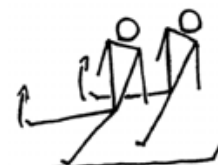

Obr. 20: „Vláček“ (Zdroj: vlastní archiv)

56. „Stěna“ (obr. 21, př́iloha 1: obr. 44) - sed zády ke stěně. Přednožit povýš $\mathrm{P} / \mathrm{L}$, unožit povýš $\mathrm{P} / \mathrm{L}$. Záda v oblasti beder nesmí být odsunuta od stěny.

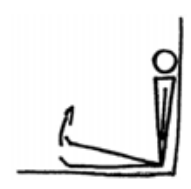

Obr. 21: ,Stěna“ (Zdroj: vlastní archiv)

\section{Klek s upažením}

57. „Kyvadlo“ (obr. 22) - klek, připažit, náklon vpřed a vzad do maximální krajní polohy.

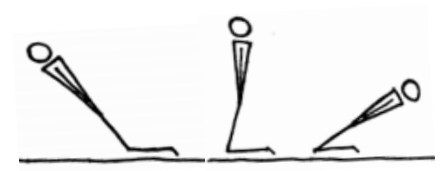

Obr. 22: „Kyvadlo“ (Zdroj: vlastní archiv)

58. „Sed na patách“ - klek sedmo, upažit povýš - klek, upažit povýš a zpět; pozice paží se nesmí měnit. 